\title{
Pengaruh Persepsi Kualitas Pelayanan, Pemahaman, Persepsi Sanksi Perpajakan, dan Lingkungan Terhadap Kepatuhan Wajib Pajak
}

\author{
Putri Noviantari ${ }^{1}$ \\ Putu Ery Setiawan ${ }^{2}$
}

${ }^{1}$ Fakultas Ekonomi dan Bisnis Universitas Udayana (Unud), Bali, Indonesia
email: putrinoviantari@ yahoo.com / Telp: +6281338633235
${ }^{2}$ Fakultas Ekonomi dan Bisnis Universitas Udayana (Unud), Bali, Indonesia

\begin{abstract}
ABSTRAK
Kepatuhan wajib pajak merupakan hal penting karena sebagian besar penerimaan negara berasal dari penerimaan pajak. Kepatuhan wajib pajak merupakan ketaatan wajib pajak untuk melakukan ketentuan-ketentuan atau aturan-aturan perpajakan yang diwajibkan. Kepatuhan wajib pajak menjadi sebuah syarat agar penerimaan negara meningkat. Kepatuhan wajib pajak adalah faktor yang penting karena fiskus menerapkan sistem self assessment dalam sistem perpajakan di Indonesia. Rendahnya kepatuhan wajib pajak dapat menyebabkan berkurangnya penerimaan ke kas negara sehingga menghambat jalannya roda pemerintahan sebab sebagian besar pengeluaran negara dibiayai oleh penerimaan pajak. Penelitian ini berfokus pada kepatuhan wajib pajak berstatus non Pengusaha Kena Pajak (PKP) di Kantor Pelayanan Pajak (KPP) Pratama Badung Selatan. Tujuan penelitian ini adalah untuk mengetahui pengaruh persepsi kualitas pelayanan, pemahaman wajib pajak, persepsi sanksi perpajakan, dan lingkungan wajib pajak terhadap kepatuhan wajib pajak berstatus non pengusaha kena pajak di Kantor Pelayanan Pratama Badung Selatan. Sampel yang digunakan adalah sebanyak 100 responden dan ditentukan dengan rumus slovin. Penentuan sampel dilakukan dengan metode sampling insidental. Pengumpulan data dilakukan dengan menyebarkan kuesioner kepada responden. Teknik analisis data yang digunakan adalah regresi linear berganda. Berdasarkan hasil analisis ditemukan bahwa persepsi kualitas pelayanan, pemahaman wajib pajak, persepsi sanksi perpajakan, dan lingkungan wajib pajak memiliki pengaruh positif dan signifikan terhadap kepatuhan wajib pajak.
\end{abstract}

Kata kunci: Kepatuhan, persepsi kualitas pelayanan, pemahaman, persepsi sanksi perpajakan, lingkungan

\footnotetext{
ABSTRACT

Taxpayer compliance is important because most of state revenues come from tax revenues. Taxpayer compliance is the taxpayer's obedience to perform the required provisions or tax rules. Taxpayer compliance becomes a requirement for increased state revenues. Taxpayer compliance is an important factor because the system implements in taxation system Indonesia is self assessment system. The low compliance of taxpayers can lead to reduced receipts to the state treasury and hindering the running of government wheels because most of state expenditures are financed by tax revenues. This study focuses on taxpayer compliance non taxable entrepreneurs in Pratama Badung Selatan tax office. The purpose of this research is to know the influence of perception of service quality, understanding of taxpayer, perception of tax sanction, and environment of taxpayer on taxpayer compliance non taxable entrepreneur in Pratama Badung Selatan tax office. The number of samples used is as much as 100 respondents and determined by the slovin formula. Sample determination was done by incidental sampling method. Data collection was done by distributing questionnaires to respondents. Data analysis technique used is multiple linear regression. Based on the results of the analysis found that the perception of service quality, understanding of taxpayers, perceptions of tax sanctions, and environmental taxpayers have a positive and significant impact on taxpayer compliance.
} 
Keywords: Compliance, perception of service quality, understanding, perception of tax sanction, environment

\section{PENDAHULUAN}

Semenjak dulu, kepatuhan Wajib Pajak telah menjadi hal penting bagi negaranegara di dunia. Alabede et. al,. (2011) menyatakan beberapa dekade belakangan ini terjadi peningkatan perhatian yang difokuskan pada masalah kepatuhan Wajib Pajak, khususnya pada negara berkembang. Bagi negara berkembang seperti Indonesia, perbaikan infrastruktur masih perlu dilakukan untuk memajukan negara dan menyejahterakan rakyat. Isu mengenai rendahnya tingkat kepatuhan Wajib Pajak menjadi sangat penting dikarenakan ketidakpatuhan perpajakan akan memunculkan upaya penghindaran dan penggelapan pajak (Sandmo, 2005).

Ketidakpatuhan Wajib Pajak secara tidak langsung menyebabkan berkurangnya penerimaan pajak ke kas negara. Berkurangnya penerimaan pajak dapat menghambat jalannya roda pemerintahan karena sebagian besar pengeluaran negara dibiayai oleh penerimaan pajak. Selain berperan dalam membiayai pembangunan, pajak juga berperan dalam membiayai pengeluaran rumah tangga pemerintahan serta sebagai alat untuk membuat kebijakan ekonomi (Poulson dan Kaplan, 2008).

Berdasarkan data pada Nota Keuangan dan RAPBN, realisasi penerimaan pajak selama kurun waktu lima tahun terakhir belum pernah mencapai target yang telah dianggarkan. Tabel 1. berikut ini menyajikan data mengenai tingkat capaian penerimaan pajak selama tahun 2011 hingga 2015. 
Tabel 1.

Tingkat Capaian Penerimaan Pajak Tahun 2011-2015 (dalam Triliun Rupiah)

\begin{tabular}{cccc}
\hline Tahun & APBN-P & Realisasi & Capaian (\%) \\
\hline 2011 & 878,69 & 873,87 & 99,45 \\
2012 & $1.016,24$ & 980,52 & 96,48 \\
2013 & $1.148,36$ & $1.077,31$ & 93,81 \\
2014 & $1.246,11$ & $1.146,87$ & 92,03 \\
2015 & $1.489,26$ & $1.240,42$ & 83,29 \\
\hline \multicolumn{2}{l}{ Sumber: Nota Keuangan dan RAPBN 2017 } & &
\end{tabular}

Pada Tabel 1. dapat dilihat bahwa sejak tahun 2011 hingga 2015, tingkat capaian penerimaan pajak justru semakin menurun. Tingkat capaian penerimaan pajak diperoleh dengan cara membandingkan angka realisasi dengan angka APBN-P. Hal ini menunjukkan bahwa kinerja pemerintah (Direktorat Jenderal Pajak) dalam memenuhi target penerimaan pajak semakin menurun.

Banyak faktor yang menyebabkan tidak tercapainya target tersebut, salah satunya adalah kepatuhan Wajib Pajak yang belum maksimal. Selain itu, dianutnya self assessment system oleh Indonesia sejak reformasi perpajakan tahun 1984 semakin menambah pentingnya kepatuhan Wajib Pajak. Menurut James dan Alley (2002), kepatuhan pajak menjadi semakin penting dengan adanya self assessment system. Self assessment system adalah sistem pemungutan pajak yang memberikan wewenang kepada Wajib Pajak untuk menghitung, menyetor, dan melaporkan sendiri kewajiban perpajakannya. Dilihat dari definisi tersebut, sistem ini menuntut adanya peran aktif masyarakat dalam pemenuhan kewajiban perpajakannya (Trisnayanti dan Jati, 2015). Dengan demikian, keberhasilan sistem ini sangat bergantung pada kepatuhan Wajib Pajak.

Salah satu hal yang dapat memengaruhi kepatuhan Wajib Pajak adalah kualitas pelayanan yang diberikan oleh petugas pajak. Menurut Gardina dan 
Haryanto (2006) dalam Fuadi dan Mangoting (2013) penyebab rendahnya kepatuhan pajak dapat disebabkan oleh kurangnya kualitas pelayanan dari petugas pajak. Palda dan Hanousek (2002) juga mengatakan bahwa kemauan Wajib Pajak untuk membayar pajak sebagian besar dipengaruhi oleh kualitas pelayanan yang diberikan oleh pemerintah. Cronin (1992) menilai kualitas pelayanan sebagai perbandingan antara harapan yang diinginkan oleh pelanggan dengan penilaian terhadap kinerja aktual dari suatu penyedia layanan. Pelayanan yang baik dan berkualitas diharapkan dapat meningkatkan kepuasan Wajib Pajak sebagai pelanggan sehingga turut meningkatkan kepatuhan dalam bidang perpajakan.

Selain kualitas pelayanan, kepatuhan Wajib Pajak juga dapat dipengaruhi oleh pemahaman Wajib Pajak. Wajib Pajak yang tidak memahami peraturan perpajakan dengan baik dan benar akan mengalami kesulitan dalam mendaftarkan diri, mengisi SPT, dan menyetorkan pajaknya, sehingga menyebabkan Wajib Pajak semakin enggan untuk mematuhi kewajiban perpajakannya. Hal tersebut ditegaskan oleh Mustofa dkk. (2016) yang menyatakan bahwa, Wajib Pajak yang kurang memahami peraturan perpajakan akan menjadikan Wajib Pajak tersebut termasuk ke dalam kelompok Wajib Pajak yang tidak patuh. Palil (2005) juga menemukan bahwa pemahaman Wajib Pajak tentang pajak yang baik akan dapat memperkecil adanya tax evasion (penggelapan pajak). Memahami peraturan perpajakan berarti memahami sanksi-sanksi yang akan didapat apabila melanggar peraturan tersebut, sehingga akan meminimalisir Wajib Pajak menjadi tidak patuh. 
Salah satu unsur yang melekat pada definisi pajak adalah pemungutannya dilaksanakan berdasarkan undang-undang dan bersifat memaksa. Hal ini berarti terdapat peraturan dalam perpajakan yang harus dipatuhi oleh Wajib Pajak serta ada sanksi bagi Wajib Pajak yang melanggar. Ali et al. (2001) dalam penelitiannya menyatakan sanksi pajak merupakan kebijakan yang efektif untuk mencegah ketidakpatuhan. Sanksi perpajakan dibuat untuk menimbulkan rasa cemas dan takut bagi Wajib Pajak yang mencoba tidak patuh terhadap kewajiban perpajakannya. Jatmiko (2006) mengatakan bahwa Wajib Pajak akan memenuhi kewajiban perpajakannya bila memandang sanksi perpajakan akan lebih banyak merugikannya. Dengan kata lain, sanksi perpajakan merupakan alat pencegah (preventif) timbulnya ketidakpatuhan Wajib Pajak.

Hal lainnya yang dapat memengaruhi kepatuhan Wajib Pajak adalah lingkungan Wajib Pajak. Lingkungan adalah sesuatu yang ada di alam sekitar yang memiliki makna dan atau pengaruh tertentu kepada individu (Widyastuti, 2015). Berdasarkan definisi tersebut dapat dikatakan bahwa lingkungan Wajib Pajak dapat memengaruhi individu untuk patuh ataupun tidak terhadap kewajiban perpajakannya. Jika lingkungan Wajib Pajak termasuk lingkungan yang patuh, maka Wajib Pajak juga memiliki kecenderungan untuk mematuhi kewajiban perpajakannya. Hal ini sesuai dengan hasil penelitian yang dilakukan oleh Santi (2012) bahwa lingkungan Wajib Pajak berpengaruh positif terhadap kepatuhan Wajib Pajak. Namun hasil penelitian yang dilakukan oleh Novitasari (2006) menyimpulkan bahwa lingkungan Wajib Pajak tidak berpengaruh terhadap kepatuhan Wajib Pajak. 
Penelitian ini berfokus pada kepatuhan Wajib Pajak berstatus non Pengusaha Kena Pajak (PKP) di Kantor Pelayanan Pajak (KPP) Pratama Badung Selatan. Berdasarkan data yang didapat dari KPP Pratama Badung Selatan, pada tahun 2015 terdapat sejumlah 45.319 Wajib Pajak non PKP yang efektif, sedangkan Wajib Pajak PKP yang efektif hanya berjumlah 768 (Sumber: KPP Pratama Badung Selatan, 2016). Dilihat dari jumlahnya, Wajib Pajak non PKP memiliki lebih banyak potensi untuk diteliti. Tingkat kepatuhan Wajib Pajak non PKP di KPP Pratama Badung Selatan juga tergolong rendah. Berikut disajikan data mengenai tingkat kepatuhan Wajib Pajak non PKP di KPP Pratama Badung Selatan selama lima tahun terakhir.

Tabel 2.

Tingkat Kepatuhan Wajib Pajak Non Pengusaha Kena Pajak di Kantor Pelayanan Pajak Pratama Badung Selatan Tahun 2011-2015

\begin{tabular}{ccccc}
\hline Tahun & $\begin{array}{c}\text { Wajib Pajak } \\
\text { Terdaftar }\end{array}$ & Wajib Pajak Efektif & $\begin{array}{c}\text { Wajib Pajak yang } \\
\text { Menyampaikan SPT }\end{array}$ & $\begin{array}{c}\text { Tingkat } \\
\text { Kepatuhan }(\%)\end{array}$ \\
\hline 2011 & 47.601 & 31.569 & 20.084 & 63,62 \\
2012 & 51.575 & 35.467 & 19.217 & 54,18 \\
2013 & 54.797 & 38.678 & 21.188 & 54,78 \\
2014 & 58.148 & 42.026 & 20.835 & 49,58 \\
2015 & 61.442 & 45.319 & 22.537 & 49,73 \\
\hline
\end{tabular}

Sumber: KPP Pratama Badung Selatan, 2016

Pada Tabel 2. di atas terlihat bahwa tingkat kepatuhan Wajib Pajak non PKP selama lima tahun terakhir mengalami fluktuasi. Pada tahun 2011, tingkat kepatuhan Wajib Pajak non PKP mencapai 63,62\%. Angka tersebut terus mengalami fluktuasi hingga tahun 2015 tingkat kepatuhan Wajib Pajak non PKP hanya 49,73\%. Berdasarkan hal tersebut, perlu diadakan kajian lebih dalam mengenai kepatuhan Wajib Pajak non PKP di KPP Pratama Badung Selatan.

Berdasarkan uraian di atas, peneliti ingin melakukan penelitian terkait pengaruh persepsi kualitas pelayanan, pemahaman Wajib Pajak, persepsi sanksi 
perpajakan, dan lingkungan Wajib Pajak terhadap kepatuhan Wajib Pajak berstatus non PKP yang berada di wilayah KPP Pratama Badung Selatan. Penelitian ini memberi kontribusi terhadap grand teori yang mendasari penelitian ini, yaitu Theory of Planned Behavior (TPB). Hasil penelitian ini menjelaskan bagaimana cara seseorang berperilaku terkait kepatuhannya sebagai Wajib Pajak sesuai dengan mekanisme theory of planned behavior. Berdasarkan TPB, Ajzen (1991) menjelaskan faktor sentral dari perilaku individu adalah bahwa perilaku itu dipengaruhi oleh niat individu (behavioral intention) terhadap perilaku tertentu tersebut. Dengan kata lain, perilaku yang ditimbulkan oleh individu muncul karena adanya niat untuk berperilaku. Sedangkan niat untuk berperilaku dipengaruhi oleh variabel sikap (attitude), norma subjektif (subjective norm), dan kontrol perilaku yang dipersepsikan (perceived behavioral control). Model kerangka TPB dipilih karena merupakan suatu model perilaku yang telah terbukti memberikan penjelasan signifikan bahwa sikap, norma subyektif, dan kontrol keperilakuan yang dipersepsikan berpengaruh terhadap perilaku patuh atau tidaknya Wajib Pajak. Penelitian sebelumnya yang menggunakan teori ini adalah penelitian yang dilakukan oleh Susmita (2016).

Menurut Kamus Besar Bahasa Indonesia dalam Rahayu (2010:38) istilah kepatuhan berarti tunduk atau patuh pada ajaran dan aturan. Aturan yang berlaku dalam perpajakan adalah Undang-Undang Perpajakan. Dalam hubungannya dengan Wajib Pajak yang patuh, maka pengertian kepatuhan Wajib Pajak merupakan suatu ketaatan Wajib Pajak untuk melakukan ketentuan-ketentuan atau aturan-aturan perpajakan yang diwajibkan atau diharuskan untuk dilaksanakan 
(Mandagi dkk., 2014). Mahendra dan Sukartha (2014) mengatakan bahwa kepatuhan Wajib Pajak menjadi sebuah syarat agar penerimaan negara meningkat. Kepatuhan Wajib Pajak adalah faktor yang penting karena fiskus menerapkan sistem self assessment dalam sistem perpajakan di Indonesia (Gunarso, 2016). Oleh karena itu, untuk meningkatkan penerimaan negara dalam sektor perpajakan khususnya yang menerapkan self assessment system, perlu dipelajari lebih jauh tentang faktor-faktor yang dapat meningkatkan kepatuhan Wajib Pajak.

Parasuraman, et. al., (1985) mengatakan bahwa kualitas pelayanan merupakan perbandingan antara harapan yang diinginkan oleh pelanggan dengan penilaian mereka terhadap kinerja aktual dari suatu penyedia layanan. Persepsi kualitas pelayanan adalah tanggapan langsung atau pandangan Wajib Pajak mengenai kualitas pelayanan yang diberikan oleh fiskus. Penelitian yang dilakukan oleh Syahril (2013) menemukan bahwa kualitas pelayanan fiskus berpengaruh signifikan positif terhadap tingkat kepatuhan Wajib Pajak. Susmita dan Supadmi (2016) dalam penelitiannya juga menyimpulkan bahwa kualitas pelayanan berpengaruh positif pada kepatuhan pelaporan Wajib Pajak Orang Pribadi di Kantor Pelayanan Pajak Pratama Denpasar Timur.

Berdasarkan theory of planned behavior, kualitas pelayanan yang diberikan fiskus kepada Wajib Pajak termasuk harapan normatif dari orang lain, dan dapat membuat Wajib Pajak termotivasi untuk memenuhi harapan tersebut (normative beliefs). Pelayanan yang baik dari fiskus akan memberikan motivasi kepada Wajib Pajak agar patuh terhadap kewajiban perpajakannya. Berdasarkan uraian tersebut dapat dikatakan bahwa semakin baik persepsi Wajib Pajak 
mengenai kualitas pelayanan yang diberikan oleh fiskus, maka akan meningkatkan kepatuhan Wajib Pajak dalam memenuhi kewajiban perpajakannya. Berdasarkan hal tersebut, hipotesis penelitian yang dirumuskan adalah.

$\mathrm{H}_{1}$ : Persepsi kualitas pelayanan berpengaruh positif terhadap kepatuhan wajib pajak.

Pemahaman Wajib Pajak tentang peraturan perpajakan adalah suatu proses dimana Wajib Pajak memahami dan mengetahui tentang peraturan dan undangundang serta tata cara perpajakan dan menerapkannya untuk melakukan kegiatan perpajakan seperti membayar pajak, melaporkan SPT, dan sebagainya (Adiasa, 2013). Berdasarkan theory of planned behavior, pemahaman Wajib Pajak termasuk behavioral beliefs sekaligus juga control beliefs. Dengan memahami perpajakan seperti fungsi pajak, hak, dan kewajibannya sebagai Wajib Pajak, individu tersebut akan memperkirakan manfaat dan hasil apa yang akan diperoleh apabila ia patuh ataupun tidak patuh terhadap kewajibannya. Selain itu, paham mengenai peraturan perpajakan berarti Wajib Pajak memahami bahwa pajak dipungut berdasarkan Undang-Undang sehingga ada kekuatan (power) yang dapat memaksa Wajib Pajak untuk patuh terhadap kewajibannya.

Wajib Pajak yang tidak memahami peraturan perpajakan secara jelas cenderung akan menjadi Wajib Pajak yang tidak taat (Julianti, 2014). Tanpa adanya pemahaman tentang pajak dan manfaatnya, tidak mungkin orang secara ikhlas membayar pajak (Susilawati dan Budiartha, 2013). Jadi, apabila Wajib Pajak paham mengenai manfaat yang diperoleh dari membayar pajak dan paham mengenai peraturan perpajakan yang berlaku, maka hal tersebut akan meningkatkan kepatuhan Wajib Pajak. Hal ini sesuai dengan penelitian 
Paramartha (2016), yang menyimpulkan bahwa pengetahuan perpajakan berpengaruh positif pada kepatuhan Wajib Pajak Badan di KPP Pratama Gianyar. Siregar (2012) dalam penelitiannya juga menyatakan bahwa pengetahuan perpajakan berpengaruh positif terhadap kepatuhan Wajib Pajak Badan. Berdasarkan uraian di atas dan hasil penelitian sebelumnya, maka hipotesis penelitian yang dirumuskan adalah.

$\mathrm{H}_{2}$ : Pemahaman wajib pajak berpengaruh positif terhadap kepatuhan wajib pajak.

Sanksi perpajakan merupakan jaminan bahwa ketentuan peraturan perundang-undangan perpajakan atau norma perpajakan akan dituruti/ditaati/dipatuhi, dengan kata lain sanksi perpajakan merupakan alat pencegah (preventif) agar Wajib Pajak tidak melanggar norma perpajakan (Mardiasmo, 2016:62). Persepsi sanksi perpajakan adalah tanggapan langsung atau pandangan Wajib Pajak mengenai berat atau ringannya sanksi perpajakan yang dirasakan.

Berdasarkan theory of planned behavior, sanksi perpajakan merupakan control beliefs karena memiliki kekuatan dalam memengaruhi perilaku individu untuk patuh ataupun tidak patuh terhadap kewajibannya. Sanksi perpajakan dibuat karena pajak dipungut berdasarkan undang-undang dan bersifat memaksa. Jatmiko (2006) menyimpulkan dalam penelitiannya bahwa sikap Wajib Pajak terhadap pelaksanaan sanksi denda berpengaruh signifikan positif terhadap kepatuhan Wajib Pajak. Sanders et al. (2008) dalam penelitiannya menyatakan bahwa sanksi perpajakan berpengaruh positif terhadap kepatuhan wajib pajak. Penelitian yang dilakukan Tiraada (2013) juga menyimpulkan bahwa sanksi pajak 
berpengaruh positif dan signifikan terhadap kepatuhan Wajib Pajak Orang Pribadi di Kabupaten Minahasa Selatan.

Pada hakikatnya, pengenaan sanksi perpajakan diberlakukan untuk menciptakan kepatuhan Wajib Pajak dalam melaksanakan kewajiban perpajakannya (Winerungan, 2013). Sanksi perpajakan diharapkan akan membuat Wajib Pajak menjadi takut untuk melakukan tindakan curang dalam perpajakan, ataupun enggan untuk sengaja melalaikan kewajiban perpajakannya. Hal serupa juga dikemukakan oleh Jatmiko (2006) yang mengatakan bahwa Wajib Pajak akan memenuhi kewajiban perpajakan bila memandang bahwa sanksi perpajakan akan lebih banyak merugikannya. Untuk mencegah ketidakpatuhan serta untuk mendorong Wajib Pajak memenuhi kewajiban perpajakannya maka haruslah diberlakukan sanksi yang tegas dalam rangka memajukan keadilan dan efektivitas sistem pajak (Webley et al, 1991). Dari pernyataan-pernyataan di atas dapat disimpulkan bahwa persepsi Wajib Pajak mengenai sanksi perpajakan dapat memengaruhi kepatuhan Wajib Pajak. Berdasarkan uraian tersebut, maka hipotesis penelitian yang dirumuskan adalah.

$\mathrm{H}_{3}$ : Persepsi sanksi perpajakan berpengaruh positif terhadap kepatuhan wajib pajak.

Lingkungan adalah sesuatu yang ada di alam sekitar yang memiliki makna dan atau pengaruh tertentu kepada individu (Widyastuti, 2015). Kepatuhan Wajib Pajak merupakan hasil secara langsung maupun tidak langsung tekanan maupun pengharapan orang-orang disekitar dan komunitas dimana wajib pajak berada. Berdasarkan theory of planned behavior, lingkungan Wajib Pajak merupakan normative beliefs. Lingkungan yang kondusif akan lebih mendukung wajib pajak 
untuk patuh. Sebaliknya, lingkungan yang kurang kondusif dimana masyarakat tidak memiliki tanggung jawab perpajakan akan menurunkan tingkat kepatuhan. Hasil penelitian Santi (2012) dan Widyastuti (2015) mengungkapkan bahwa lingkungan berpengaruh positif dan signifikan terhadap kepatuhan pajak. Semakin baik lingkungan yang berarti lingkungan mendukung pelaksanaan kewajiban perpajakan maka semakin tinggi pula kepatuhan perpajakan. Berdasarkan penjabaran di atas, maka dirumuskan hipotesis sebagai berikut.

$\mathrm{H}_{4}$ : Lingkungan wajib pajak berpengaruh positif terhadap kepatuhan wajib pajak.

\section{METODE PENELITIAN}

Penelitian ini dilakukan di Kantor Pelayanan Pajak (KPP) Pratama Badung Selatan yang beralamat di Jalan Kapten Tantular No. 4 GKN II, Renon Denpasar. Lokasi ini dipilih dikarenakan kepatuhan Wajib Pajak berstatus non PKP di KPP Pratama Badung Selatan mengalami fluktuasi pada 5 (lima) tahun terakhir dan pada tahun 2015 tingkat kepatuhan tersebut berada di bawah 50\%. Penelitian ini menggunakan pendekatan kuantitatif dengan tingkat eksplanasi penelitian berbentuk asosiatif. Desain penelitian ini dapat digambarkan seperti pada gambar berikut.

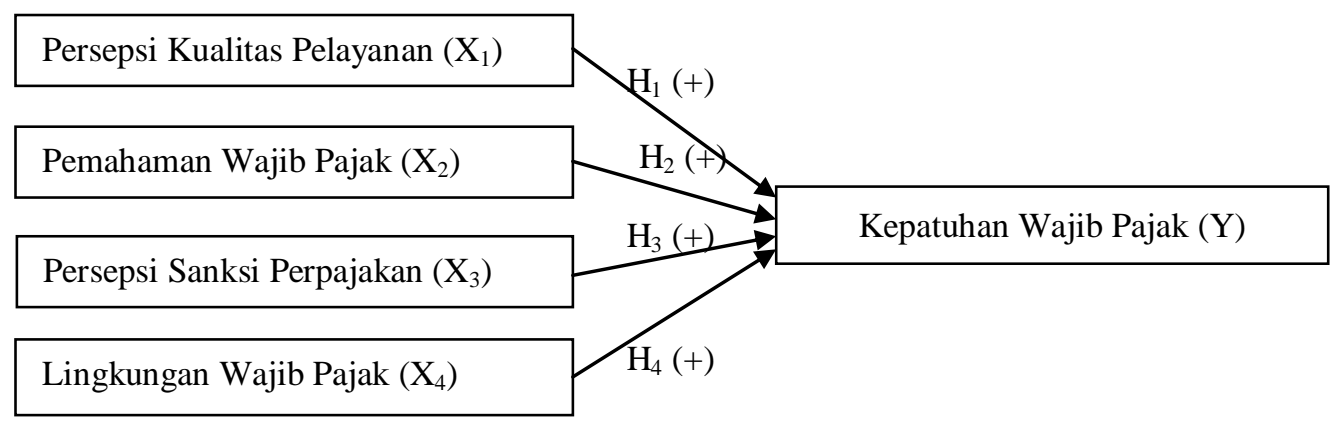

Sumber: Data diolah, 2017

Gambar 1. Desain Penelitian 
Penelitian ini menggunakan data kualitatif berupa gambaran umum, sejarah, dan struktur organisasi KPP Pratama Badung Selatan. Data kuantitatif dalam penelitian ini adalah data mengenai Wajib Pajak berstatus non PKP di KPP Pratama Badung Selatan, seperti data mengenai jumlah terdaftar, jumlah efektif, dan jumlah yang menyampaikan SPT, serta jawaban responden terhadap pernyataan maupun pertanyaan pada kuesioner yang telah dikuantitatifkan. Jenis data yang digunakan dalam penelitian ini menurut sumbernya terdiri dari data primer dan sekunder. Data primer dalam penelitian ini adalah jawaban responden yang diperoleh langsung dari Wajib Pajak berstatus non PKP di KPP Pratama Badung Selatan dan gambaran umum, sejarah, serta struktur organisasi KPP Pratama Badung Selatan. Data sekunder dalam penelitian ini adalah data mengenai Wajib Pajak berstatus non PKP di KPP Pratama Badung Selatan, seperti data mengenai jumlah terdaftar, jumlah efektif, dan jumlah yang menyampaikan SPT.

Variabel terikat dalam penelitian ini adalah kepatuhan Wajib Pajak (Y). Kepatuhan Wajib Pajak merupakan suatu ketaatan untuk melakukan ketentuanketentuan atau aturan-aturan perpajakan yang diwajibkan atau diharuskan untuk dilaksanakan oleh Wajib Pajak. Indikator yang digunakan untuk mengukur kepatuhan Wajib Pajak mengacu pada penelitian Pratiwi (2015), antara lain: a) Kepemilikan NPWP; b) Penyampaian dan pelaporan SPT; c) Menghitung dan membayar pajak terutang dengan benar dan tepat waktu; d) Mengisi SSP/SPT dengan benar; e) Tidak ada tunggakan pajak. Pengukuran variabel kepatuhan Wajib Pajak menggunakan teknik pengukuran skala likert 4 poin. 
Variabel bebas dalam penelitian ini adalah persepsi kualitas pelayanan $\left(\mathrm{X}_{1}\right)$, pemahaman Wajib Pajak $\left(\mathrm{X}_{2}\right)$, persepsi sanksi perpajakan $\left(\mathrm{X}_{3}\right)$, dan lingkungan Wajib Pajak $\left(\mathrm{X}_{4}\right)$. Persepsi kualitas pelayanan adalah tanggapan langsung atau pandangan Wajib Pajak mengenai kualitas pelayanan yang diberikan oleh fiskus. Kualitas pelayanan merupakan perbandingan antara harapan yang diinginkan oleh pelanggan dengan penilaian mereka terhadap kinerja aktual dari suatu penyedia layanan (Parasuraman et al., 1985). Indikator yang digunakan untuk mengukur persepsi kualitas pelayanan mengacu pada lima dimensi kualitas pelayanan, seperti yang digunakan dalam penelitian Susmita (2015), antara lain: a) Tangibles (bukti fisik); b) Reliability (keandalan); c) Responsiveness (daya tanggap); d) Assurances (jaminan); e) Empathy (empati). Pengukuran variabel kualitas pelayanan menggunakan teknik pengukuran skala likert 4 poin.

Pemahaman Wajib Pajak tentang peraturan perpajakan adalah suatu proses dimana Wajib Pajak memahami dan mengetahui tentang peraturan dan undangundang serta tata cara perpajakan dan menerapkannya untuk melakukan kegiatan perpajakan seperti membayar pajak, melaporkan SPT, dan sebagainya (Adiasa, 2013). Indikator yang digunakan untuk mengukur pemahaman Wajib Pajak tentang peraturan perpajakan mengacu pada penelitian yang dilakukan oleh Masruroh (2013) antara lain: 1) Paham tata cara penghitungan pajak terutang; 2) Paham tata cara pembayaran pajak; 3) Paham tata cara pengisian Surat Pemberitahuan (SPT); 4) Paham tata cara penyampaian Surat Pemberitahuan (SPT); 5) Paham atas sanksi keterlambatan. Pengukuran variabel pemahaman Wajib Pajak menggunakan teknik pengukuran skala likert 4 poin. 
Persepsi sanksi perpajakan adalah tanggapan langsung atau pandangan Wajib Pajak mengenai berat atau ringannya sanksi perpajakan yang dirasakan. Indikator yang digunakan untuk mengukur persepsi sanksi perpajakan mengacu pada penelitian yang dilakukan oleh Muliari dan Setiawan (2011), yaitu: 1) Pengenaan sanksi yang cukup berat merupakan salah satu sarana untuk mendidik Wajib Pajak; 2) Sanksi pajak harus dikenakan kepada pelanggarnya tanpa toleransi; 3) Pengenaan sanksi pajak atas pelanggaran pajak tidak dapat dinegosiasikan; 4) Sanksi administrasi yang dikenakan bagi pelanggar aturan pajak cukup berat; 5) Sanksi pidana yang dikenakan bagi pelanggar aturan pajak cukup berat. Pengukuran variabel sanksi perpajakan menggunakan teknik pengukuran skala likert 4 poin.

Lingkungan Wajib Pajak merupakan keadaan atau kondisi di sekitar Wajib Pajak yang dapat memberikan pengaruh terhadap kewajiban perpajakannya. Lingkungan Wajib Pajak ditunjukkan dengan perhatian masyarakat terhadap kewajiban perpajakannya dan kebiasaan masyarakat itu sendiri terhadap memenuhi kewajibannya. Indikator variabel ini mengacu pada penelitian Santi (2012), yaitu: 1) Kepatuhan masyarakat di sekitar Wajib Pajak terhadap kewajiban perpajakannya; 2) Perilaku masyarakat di sekitar Wajib Pajak terkait dengan pembayaran dan pelaporan pajak. Pengukuran variabel lingkungan Wajib Pajak menggunakan teknik pengukuran skala likert 4 poin.

Populasi dalam penelitian ini adalah seluruh Wajib Pajak non PKP efektif yang terdaftar di KPP Pratama Badung Selatan. Sampel pada penelitian ini ditentukan menggunakan metode sampling insidental. Jumlah dan ukuran sampel 
ditentukan dengan menggunakan rumus Slovin (Umar, 2008:67). Rumus Slovin digunakan karena jumlah populasi telah diketahui dan penghitungan menggunakan rumus ini cukup sederhana, yaitu:

$\mathrm{n}=\frac{\mathrm{N}}{\left(1+\mathrm{Ne}^{2}\right)}$

Keterangan:

$\mathrm{n}$ : ukuran sampel

$\mathrm{N}$ : ukuran populasi

e : kelonggaran ketidaktelitian karena kesalahan pengambilan sampel yang ditoleransi, pada penelitian ini adalah $10 \%$

Berdasarkan data dari KPP Pratama Badung Selatan, diketahui jumlah populasi dari Wajib Pajak non PKP efektif sebanyak 45.319. Besarnya sampel dalam penelitian ini dengan menggunakan rumus Slovin adalah:

$$
\mathrm{n}=\frac{45.319}{1+45.319(0,1)^{2}}=99,78
$$

Banyaknya sampel yang diambil pada penelitian ini adalah sebanyak 99,78 yang dibulatkan menjadi 100 Wajib Pajak non PKP.

Teknik pengumpulan data yang digunakan pada penelitian ini adalah kuesioner dan observasi nonpartisipan. Pada penelitian ini kuesioner diberikan secara langsung kepada responden di lokasi penelitian yang telah memenuhi syarat yaitu memiliki NPWP dan berstatus non PKP, kemudian peneliti menunggu hingga kuesioner tersebut diisi lengkap oleh responden.

Teknik analisis data yang digunakan pada penelitian ini adalah teknik analisis regresi linear berganda. Analisis regresi pada dasarnya adalah studi mengenai ketergantungan variabel dependen (terikat) dengan satu atau lebih variabel independen (variabel penjelas/bebas) (Ghozali, 2013:95). Pada penelitian 
ini analisis regresi linear berganda digunakan untuk mengetahui pengaruh kualitas pelayanan, pemahaman Wajib Pajak, sanksi perpajakan, dan lingkungan Wajib Pajak terhadap kepatuhan WP non PKP. Model regresi linear berganda dirumuskan sebagai berikut (Sugiyono, 2014:277):

$\mathrm{Y}=\alpha+\beta_{1} \mathrm{X}_{1}+\beta_{2} \mathrm{X}_{2}+\beta_{3} \mathrm{X}_{3}+\beta_{4} \mathrm{X}_{4}+\mathrm{e}$

Keterangan:

$\beta_{1}, \beta_{2}, \beta_{3}, \beta_{4} \quad$ : Koefisien regresi variabel independen

$\mathrm{X}_{1} \quad$ : Persepsi kualitas pelayanan

$\mathrm{X}_{2} \quad$ : Pemahaman wajib pajak

$\mathrm{X}_{3} \quad$ : Persepsi sanksi perpajakan

$\mathrm{X}_{4} \quad$ : Lingkungan wajib pajak

$\mathrm{Y} \quad$ : Kepatuhan wajib pajak non PKP

$\varepsilon \quad:$ Standar error

\section{HASIL DAN PEMBAHASAN}

Berdasarkan Tabel 3. dapat diketahui bahwa variabel persepsi kualitas pelayanan memiliki nilai rata-rata sebesar 3,196 dengan penyimpangan baku sebesar 0,3364. Nilai minimum variabel persepsi kualitas pelayanan adalah sebesar 2,3 dan nilai maksimum adalah sebesar 4,0. Variabel pemahaman Wajib Pajak memiliki nilai rata-rata sebesar 3,209 dengan penyimpangan baku sebesar 0,4349. Nilai minimum variabel pemahaman Wajib Pajak adalah sebesar 2,3 dan nilai maksimum adalah sebesar 4,0.

Tabel 3.

Hasil Analisis Statistik Deskriptif

\begin{tabular}{lccccc}
\hline \multicolumn{1}{c}{ Variabel } & N & Minimum & Maximum & Mean & $\begin{array}{c}\text { Std. } \\
\text { Deviation }\end{array}$ \\
\hline Persepsi Kualitas Pelayanan & 100 & 2,3 & 4,0 & 3,196 & 0,3364 \\
Pemahaman Wajib Pajak & 100 & 2,3 & 4,0 & 3,209 & 0,4349 \\
Persepsi Sanksi Perpajakan & 100 & 2,4 & 4,0 & 3,064 & 0,4059 \\
Lingkungan Wajib Pajak & 100 & 2,0 & 4,0 & 2,970 & 0,4074 \\
Kepatuhan Wajib Pajak & 100 & 2,0 & 4,0 & 3,107 & 0,3712 \\
Valid N (listwise) & 100 & & & & \\
\hline
\end{tabular}

Sumber: Data diolah, 2017 
Putri Noviantari dan Putu Ery Setiawan. Pengaruh ...

Variabel persepsi sanksi perpajakan memiliki nilai rata-rata sebesar 3,064 dengan penyimpangan baku sebesar 0,4059. Nilai minimum variabel persepsi sanksi perpajakan adalah sebesar 2,4 dan nilai maksimum sebesar 4,0 . Variabel lingkungan Wajib Pajak memiliki nilai rata-rata sebesar 2,970 dengan penyimpangan baku sebesar 0,4074. Nilai minimum variabel lingkungan Wajib Pajak adalah sebesar 2,0 dan nilai maksimum sebesar 4,0. Variabel kepatuhan Wajib Pajak memiliki nilai rata-rata sebesar 3,107 dengan penyimpangan baku sebesar 0,4059. Nilai minimum variabel kepatuhan Wajib Pajak adalah sebesar 2,0 dan nilai maksimum sebesar 4,0.

Uji validitas digunakan untuk mengukur sah atau valid tidaknya suatu kuesioner. Pengujian validitas dapat dilakukan dengan analisis faktor, yaitu dengan mengorelasikan antara skor item intrumen dalam suatu faktor dengan skor total sehingga didapat nilai pearson correlation. Jika nilai $\mathrm{r}$ pearson correlation terhadap skor total diatas 0,30 , maka suatu instrumen dikatakan valid. Seluruh item pertanyaan yang digunakan dalam penelitian ini adalah valid, dimana nilai pearson correlation yang diperoleh dari masing-masing item pertanyaan lebih besar 0,30 .

Tabel 4.

Hasil Uji Reliabilitas

\begin{tabular}{lcc}
\hline \multicolumn{1}{c}{ Variabel } & Cronbach's Alpha & Keterangan \\
\hline Kepatuhan Wajib Pajak $(\mathrm{Y})$ & 0,852 & Reliabel \\
Persepsi Kualitas Pelayanan $\left(\mathrm{X}_{1}\right)$ & 0,917 & Reliabel \\
Pemahaman Wajib Pajak $\left(\mathrm{X}_{2}\right)$ & 0,950 & Reliabel \\
Persepsi Sanksi Perpajakan $\left(\mathrm{X}_{3}\right)$ & 0,811 & Reliabel \\
Lingkungan Wajib Pajak $\left(\mathrm{X}_{4}\right)$ & 0,896 & Reliabel \\
\hline Sumber: Data diolah, 2017 & &
\end{tabular}


Tabel 4 menunjukkan bahwa Cronbach's Alpha dari seluruh variabel lebih besar dari 0,70, maka dapat disimpulkan bahwa instrumen kuesioner tersebut reliabel.

Hasil uji normalitas menunjukkan nilai Asymp. Sig (2-tailed) adalah sebesar 0,145 yang berarti nilai tersebut lebih besar dari taraf signifikan 0,05. Hal tersebut menyimpulkan bahwa variabel dalam model ini berdistribusi secara normal. Hasil uji multikolinearitas menunjukkan bahwa nilai tolerance masingmasing variabel bebas lebih besar dari 0,1 dan nilai VIF lebih kecil dari 10 , sehingga dapat dinyatakan bahwa dalam model regresi ini tidak terjadi gejala multikolinearitas. Hasil uji heteroskedastisitas menunjukkan nilai signifikan masing-masing variabel lebih besar dari 0,05 yang berarti model regresi penelitian ini terbebas dari heteroskedastisitas. Berdasarkan hasil tersebut maka dapat disimpulkan bahwa model regresi penelitian ini telah lolos uji asumsi klasik.

Tabel 5.

Hasil Regresi Linear Berganda

\begin{tabular}{lrrrrr}
\hline \multicolumn{1}{c}{ Model } & \multicolumn{2}{c}{$\begin{array}{c}\text { Unstandardized } \\
\text { Coefficients }\end{array}$} & $\begin{array}{c}\text { Standardized } \\
\text { Coefficients }\end{array}$ & T & Sig. \\
\cline { 2 - 4 } & \multicolumn{1}{c}{ B } & Std. Error & Beta & & \\
\hline (Constant) & $-2,588$ & 1,459 & & $-1,773$ & 0,079 \\
Persepsi Kualitas Pelayanan & 0,152 & 0,023 & 0,415 & 6,591 & 0,000 \\
Pemahaman Wajib Pajak & 0,245 & 0,039 & 0,430 & 6,289 & 0,000 \\
Persepsi Sanksi Perpajakan & 0,167 & 0,061 & 0,152 & 2,740 & 0,007 \\
Lingkungan Wajib Pajak & 0,191 & 0,083 & 0,175 & 2,312 & 0,023 \\
\hline
\end{tabular}

Sumber: Data Diolah, 2017

Berdasarkan Tabel 5, model regresi yang digunakan adalah sebagai berikut:

$$
Y=-2,588+0,152 X_{1}+0,245 X_{2}+0,167 X_{3}+0,191 X_{4}+e
$$

Konstanta sebesar -2,588 secara matematis menunjukkan bahwa jika persepsi kualitas pelayanan $\left(\mathrm{X}_{1}\right)$, pemahaman Wajib Pajak $\left(\mathrm{X}_{2}\right)$, persepsi sanksi perpajakan $\left(\mathrm{X}_{3}\right)$, dan lingkungan Wajib Pajak $\left(\mathrm{X}_{4}\right)$ sama dengan nol, maka 
kepatuhan Wajib Pajak (Y) adalah sebesar -2,588 satuan. Nilai koefisien regresi persepsi kualitas pelayanan $\left(\mathrm{X}_{1}\right)=0,152$ menunjukkan terdapat pengaruh positif antara variabel persepsi kualitas pelayanan $\left(\mathrm{X}_{1}\right)$ terhadap variabel kepatuhan Wajib Pajak (Y) sebesar 0,152. Artinya apabila persepsi kualitas pelayanan $\left(\mathrm{X}_{1}\right)$ naik sebesar 1 (satu) satuan sementara pemahaman Wajib Pajak $\left(\mathrm{X}_{2}\right)$, persepsi sanksi perpajakan $\left(\mathrm{X}_{3}\right)$, dan lingkungan Wajib Pajak $\left(\mathrm{X}_{4}\right)$ diasumsikan tetap, maka kepatuhan Wajib Pajak (Y) akan meningkat sebesar 0,152 satuan.

Nilai koefisien regresi pemahaman Wajib Pajak $\left(\mathrm{X}_{2}\right)=0,245$ menunjukkan bahwa terdapat pengaruh positif antara variabel pemahaman Wajib Pajak $\left(\mathrm{X}_{2}\right)$ terhadap variabel kepatuhan Wajib Pajak $(\mathrm{Y})$ sebesar 0,245. Artinya apabila pemahaman Wajib Pajak $\left(\mathrm{X}_{2}\right)$ naik sebesar 1 (satu) satuan sementara persepsi kualitas pelayanan $\left(\mathrm{X}_{1}\right)$, persepsi sanksi perpajakan $\left(\mathrm{X}_{3}\right)$, dan lingkungan Wajib Pajak $\left(\mathrm{X}_{4}\right)$ diasumsikan tetap, maka kepatuhan Wajib Pajak (Y) akan meningkat sebesar 0,245 satuan.

Nilai koefisien regresi persepsi sanksi perpajakan $\left(\mathrm{X}_{3}\right)=0,167$ menunjukkan bahwa terdapat pengaruh positif antara variabel persepsi sanksi perpajakan $\left(\mathrm{X}_{3}\right)$ terhadap variabel kepatuhan Wajib Pajak (Y) sebesar 0,167. Artinya apabila persepsi sanksi perpajakan $\left(\mathrm{X}_{3}\right)$ naik sebesar 1 (satu) satuan sementara persepsi kualitas pelayanan $\left(\mathrm{X}_{1}\right)$, pemahaman Wajib Pajak $\left(\mathrm{X}_{2}\right)$, dan lingkungan Wajib Pajak $\left(\mathrm{X}_{4}\right)$ diasumsikan tetap, maka kepatuhan Wajib Pajak (Y) akan meningkat sebesar 0,167 satuan.

Nilai koefisien regresi lingkungan Wajib Pajak $\left(\mathrm{X}_{4}\right)=0,191$ menunjukkan bahwa terdapat pengaruh positif antara variabel lingkungan Wajib Pajak $\left(\mathrm{X}_{4}\right)$ 
terhadap variabel kepatuhan Wajib Pajak (Y) sebesar 0,191. Artinya apabila lingkungan Wajib Pajak $\left(\mathrm{X}_{4}\right)$ naik sebesar 1 (satu) satuan sementara persepsi kualitas pelayanan $\left(\mathrm{X}_{1}\right)$, pemahaman Wajib Pajak $\left(\mathrm{X}_{2}\right)$, dan persepsi sanksi perpajakan $\left(\mathrm{X}_{3}\right)$ diasumsikan tetap, maka kepatuhan Wajib Pajak (Y) akan meningkat sebesar 0,191 satuan.

Tabel 6.

\section{Hasil Koefisien Determinasi}

\begin{tabular}{lcccr}
\hline Model & R & R Square & Adjusted R Square & Std. Error of the Estimate \\
\hline 1 & $0,849(\mathrm{a})$ & 0,721 & 0,709 & 1,201 \\
\hline Sumber: Data diolah, 2017 & & &
\end{tabular}

Tabel 6. menunjukkan bahwa Adjusted $\mathrm{R}^{2}$ adalah sebesar 0,709. Hal tersebut memiliki arti bahwa variasi kepatuhan Wajib Pajak dapat dijelaskan oleh variasi persepsi kualitas pelayanan, pemahaman Wajib Pajak, persepsi sanksi perpajakan, dan lingkungan Wajib Pajak sebesar 70,9\%, sedangkan sisanya sebesar 29,1\% dijelaskan oleh faktor-faktor lain di luar model.

Tabel 7.

Hasil Uji Kelayakan Model (Uji F)

\begin{tabular}{lrrrll}
\hline \multicolumn{1}{c}{ Model } & Sum of Squares & \multicolumn{1}{c}{ df } & Mean Square & F & Sig. \\
\hline Regression & 353,966 & 4 & 88,492 & 61,330 & $0,000(\mathrm{a})$ \\
Residual & 137,074 & 95 & 1,443 & & \\
Total & 491,040 & 99 & & & \\
\hline
\end{tabular}

Sumber: Data diolah, 2017

Tabel 7. menunjukkan bahwa nilai $\mathrm{F}$ hitung adalah sebesar 61,330 dengan signifikansi $F=0,000<\alpha=0,05$, sehingga dapat disimpulkan model penelitian ini adalah layak. Hasil ini memberikan makna bahwa persepsi kualitas pelayanan, pemahaman Wajib Pajak, persepsi sanksi perpajakan, dan lingkungan Wajib Pajak mampu memprediksi atau menjelaskan kepatuhan Wajib Pajak.

Berdasarkan hasil perhitungan yang ditunjukkan pada Tabel 5. diketahui bahwa nilai $\beta_{1}=0,152$. Hal ini menunjukkan bahwa pengaruh persepsi kualitas 
pelayanan terhadap kepatuhan Wajib Pajak adalah positif. Nilai signifikansi t adalah sebesar 0,000 yang berarti lebih kecil apabila dibandingkan dengan taraf signifikansi yang digunakan yaitu $\alpha=0,05$. Hal ini menunjukkan bahwa variabel persepsi kualitas pelayanan berpengaruh positif dan signifikan terhadap kepatuhan Wajib Pajak sehinggan hipotesis pertama $\left(\mathrm{H}_{1}\right)$ diterima. Pelayanan yang diberikan oleh fiskus secara langsung akan memengaruhi persepsi Wajib Pajak mengenai kualitas pelayanan tersebut. Pelayanan yang dinilai berkualitas akan memberikan kepuasan kepada Wajib Pajak sehingga akan mendorong Wajib Pajak untuk kembali memenuhi kewajiban perpajakannya. Sebaliknya, pelayanan yang tidak memenuhi harapan Wajib Pajak akan membuat Wajib Pajak semakin enggan untuk berurusan kembali dengan fiskus, yang menyebabkan Wajib Pajak cenderung untuk tidak patuh.

Hasil penelitian ini sesuai dengan penelitian yang dilakukan oleh Syahril (2013) di KPP Pratama Kota Solok, dengan Wajib Pajak orang yang melakukan usaha perdagangan sebagai sampelnya, yang menyimpulkan bahwa kualitas pelayanan fiskus berpengaruh signifikan positif terhadap tingkat kepatuhan Wajib Pajak. Hasil penelitian ini juga sesuai dengan penelitian yang dilakukan oleh Susmita dan Supadmi (2016) di KPP Pratama Denpasar Timur, yang menyimpulkan bahwa kualitas pelayanan berpengaruh positif dan signifikan terhadap kepatuhan Wajib Pajak Orang Pribadi.

Berdasarkan hasil perhitungan yang ditunjukkan pada Tabel 5. diketahui bahwa nilai $\beta_{2}=0,245$. Hal ini menunjukkan bahwa pengaruh pemahaman Wajib Pajak terhadap kepatuhan Wajib Pajak adalah positif. Nilai signifikansi t adalah 
sebesar 0,000 yang berarti lebih kecil apabila dibandingkan dengan taraf signifikansi yang digunakan yaitu $\alpha=0,05$. Hal ini menunjukkan bahwa variabel pemahaman Wajib Pajak berpengaruh positif dan signifikan terhadap kepatuhan Wajib Pajak sehingga hipotesis kedua $\left(\mathrm{H}_{2}\right)$ diterima. Pemahaman Wajib Pajak merupakan ukuran Wajib Pajak dalam memahami perpajakan. Semakin tinggi tingkat pemahaman Wajib Pajak mengenai peraturan perpajakan, maka kepatuhan Wajib Pajak juga akan semakin meningkat. Hal tersebut dapat dijelaskan karena adanya peraturan perpajakan yang harus dipahami oleh Wajib Pajak dalam memenuhi kewajibannya. Wajib Pajak yang memahami tata cara dalam penghitungan, pembayaran, pelaporan pajak, pengisian serta pelaporan SPT akan lebih mudah dalam melaksanakan kewajiban perpajakannya dibandingkan dengan Wajib Pajak yang tidak paham. Hasil penelitian ini sesuai dengan penelitian yang dilakukan oleh Paramartha (2016) yang dilakukan di KPP Pratama Gianyar. Penelitian tersebut menyimpulkan bahwa kualitas pelayanan berpengaruh positif pada kepatuhan Wajib Pajak Badan.

Berdasarkan hasil perhitungan yang ditunjukan pada Tabel 5. diketahui bahwa nilai $\beta_{3}=0,167$. Hal ini menunjukkan bahwa pengaruh persepsi sanksi perpajakan terhadap kepatuhan Wajib Pajak adalah positif. Nilai signifikansi t adalah sebesar 0,007 yang berarti lebih kecil apabila dibandingkan dengan taraf signifikansi yang digunakan yaitu $\alpha=0,05$. Hal ini menunjukkan bahwa variabel persepsi sanksi perpajakan berpengaruh positif signifikan terhadap kepatuhan Wajib Pajak sehingga hipotesis ketiga $\left(\mathrm{H}_{3}\right)$ diterima. Persepsi sanksi perpajakan adalah tanggapan langsung atau pandangan Wajib Pajak mengenai berat atau 
ringannya sanksi perpajakan yang dirasakan. Semakin berat sanksi yang harus ditanggung oleh Wajib Pajak akibat kelalaiannya, maka akan membuat Wajib Pajak semakin enggan untuk melalaikan kewajibannya. Hal tersebut akan mendorong Wajib Pajak untuk patuh terhadap kewajiban perpajakannya. Hasil penelitian ini sesuai dengan penelitian yang dilakukan oleh Jatmiko (2006) yang menyimpulkan bahwa sikap Wajib Pajak terhadap pelaksanaan sanksi denda berpengaruh positif signifikan terhadap kepatuhan Wajib Pajak. Penelitian tersebut menggunakan Wajib Pajak di Kota Semarang sebagai sampelnya.

Berdasarkan hasil perhitungan yang ditunjukan pada Tabel 5. diketahui bahwa nilai $\beta_{4}=0,191$. Hal ini menunjukkan bahwa pengaruh lingkungan Wajib Pajak terhadap kepatuhan Wajib Pajak adalah positif. Nilai signifikansi t adalah sebesar 0,023 yang berarti lebih kecil apabila dibandingkan dengan taraf signifikansi yang digunakan yaitu $\alpha=0,05$. Hal ini menunjukkan bahwa variabel lingkungan Wajib Pajak berpengaruh positif dan signifikan terhadap kepatuhan Wajib Pajak sehingga hipotesis keempat $\left(\mathrm{H}_{4}\right)$ diterima. Lingkungan Wajib Pajak merupakan keadaan atau kondisi di sekitar Wajib Pajak yang dapat memberikan pengaruh terhadap kewajiban perpajakannya. Lingkungan Wajib Pajak yang baik dapat dilihat dari tingginya perhatian masyarakat di sekitar Wajib Pajak terhadap kewajiban perpajakannya, yang berarti lingkungan tersebut mendukung pelaksanaan kewajiban perpajakan.

Semakin baik lingkungan di sekitar Wajib Pajak akan memberikan pengaruh bagi Wajib Pajak tersebut untuk ikut melaksanakan kewajiban perpajakannya. Hal tersebut dikarenakan Wajib Pajak menganggap perilaku 
masyarakat di sekitarnya dapat menjadi contoh untuk berperilaku patuh maupun tidak patuh dalam melaksanakan kewajiban perpajakannya. Wajib Pajak beranggapan bahwa apabila ia ingin berperilaku tidak patuh, ia dapat menjadikan orang yang ia contoh sebagai pembenaran atas perilakunya. Sebaliknya, perilaku patuh dalam lingkungan Wajib Pajak akan menjadi suatu motivasi bagi Wajib Pajak untuk memenuhi kewajibannya. Hasil penelitian ini sesuai dengan penelitian yang dilakukan oleh Santi (2012) yang menyimpulkan bahwa lingkungan berpengaruh positif dan signifikan terhadap kepatuhan Wajib Pajak. Penelitian Santi (2012) mengambil lokasi di Semarang dan menggunakan Wajib Pajak Orang Pribadi sebagai sampel penelitiannya.

\section{SIMPULAN}

Berdasarkan hasil analisis dan pembahasan, maka dapat disimpulkan bahwa persepsi kualitas pelayanan berpengaruh positif terhadap kepatuhan Wajib Pajak. Hal ini menunjukkan bahwa semakin baik persepsi Wajib Pajak mengenai kualitas pelayanan yang diberikan oleh fiskus, maka kepatuhan Wajib Pajak juga akan meningkat. Pemahaman Wajib Pajak berpengaruh positif terhadap kepatuhan Wajib Pajak. Hal ini menunjukkan bahwa semakin tinggi pemahaman Wajib Pajak mengenai peraturan perpajakan, maka kepatuhan Wajib Pajak juga akan meningkat.

Persepsi sanksi perpajakan berpengaruh positif terhadap kepatuhan Wajib Pajak. Hal ini menunjukkan bahwa semakin tinggi persepsi sanksi perpajakan atau semakin berat sanksi perpajakan yang dirasakan oleh Wajib Pajak, maka kepatuhan Wajib Pajak juga akan meningkat. Lingkungan Wajib Pajak 
berpengaruh positif terhadap kepatuhan Wajib Pajak. Hal ini menunjukkan bahwa semakin baik lingkungan Wajib Pajak, maka kepatuhan Wajib Pajak juga akan meningkat. Saran yang dapat diberikan bagi peneliti selanjutnya yang ingin melakukan kajian pada bidang yang sama dapat menambah variabel-variabel yang belum digunakan pada penelitian ini, seperti variabel kesadaran Wajib Pajak, penerapan e-filing, atau kondisi keuangan Wajib Pajak. Hal ini dikarenakan nilai koefisien determinasi pada penelitian ini masih dapat ditingkatkan dengan adanya penambahan variabel independen.

\section{REFERENSI}

Adiasa, Nirawan. 2013. Pengaruh Pemahaman Peraturan Pajak terhadap Kepatuhan Wajib Pajak dengan Preferensi Risiko sebagai Variabel Moderating. Skripsi Jurusan Akuntansi Fakultas Ekonomi Universitas Negeri Semarang. Semarang.

Alabede, James O., Ariffin, Zaimah Bt. Zainol, Idris, Kamil Md.. 2011. Public Governance Quality and Tax Compliance Behavior in Nigeria: The Moderating Role of Financial Condition and Risk Preference. Issues in Social and Environmental Accounting, 5 (1), pp:3-24.

Ajzen, Icek. 1991. The Theory of Planned Behavior. Organizational Behavior and Human Decision Process, Vol. 50, pp:179-211.

Cronin, J., Joseph, Steven A. Taylor. 1992. Measuring Service Quality. Journal of Marketing, 56, h:55-68.

Fuadi, Arabella Oentari dan Yenni Mangoting. 2013. Pengaruh Kualitas Pelayanan Petugas Pajak, Sanksi Perpajakan, dan Biaya Kepatuhan Pajak terhadap Kepatuhan Wajib Pajak UMKM. Tax and Accounting Review, 1 (1).

Ghozali, Imam. 2013. Aplikasi Analisis Multivariate dengan Program IBM SPSS 21. Semarang: Universitas Diponegoro.

Gunarso, Pujo. 2016. Pemeriksaan Pajak dan Sanksi Pajak terhadap Kepatuhan Wajib Pajak Badan pada KPP Kepanjen Kabupaten Malang. Jurnal Keuangan dan Perbankan, 20 (2), h:214-223. 
James, Simon and Clinton Alley. 2010. Tax Compliance, Self-assessment and Tax Administration. MPRA Paper, No. 26906, posted 22, November 2010.

Jatmiko, Agus Nugroho. 2006. Pengaruh Sikap Wajib Pajak pada Pelaksanaan Sanksi Denda, Pelayanan Fiskus dan Kesadaran Perpajakan terhadap Kepatuhan Wajib Pajak (Studi Empiris terhadap Wajib Pajak Orang Pribadi di Kota Semarang). Tesis Program Pasca Sarjana Magister Akuntansi Universitas Diponegoro. Semarang.

Julianti, Murni. 2014. Analisis Faktor-faktor yang Mempengaruhi Kepatuhan Wajib Pajak Orang Pribadi untuk Membayar Pajak dengan Kondisi Keuangan dan Preferensi Risiko Wajib Pajak sebagai Variabel Moderating. Skripsi Fakultas Ekonomika dan Bisnis Universitas Dipenogoro. Semarang.

Mahendra, Putu Putra dan I Made Sukartha. 2014. Pengaruh Kepatuhan, Pemeriksaan, dan Penagihan Pajak pada Penerimaan Pajak Penghasilan Badan. E-Jurnal Akuntansi Universitas Udayana, 9 (3), h:633-643.

Mandagi, C., H. Sabijono, dan V. Tirayoh. 2014. Pengaruh Pemeriksaan Pajak terhadap Tingkat Kepatuhan Wajib Pajak Badan dalam Memenuhi Kewajiban Perpajakannya pada KPP Pratama Manado. Jurnal EMBA, 2 (3), h:1665-1674.

Mardiasmo. 2016. Perpajakan. Edisi Terbaru 2016. Yogyakarta: Andi.

Masruroh, Siti. 2013. Pengaruh Kemanfaatan NPWP, Pemahaman Wajib Pajak, Kualitas Pelayanan, dan Sanksi Perpajakan terhadap Kepatuhan Wajib Pajak (Studi Empiris pada WP OP di Kabupaten Tegal). Skripsi Program Sarjana Fakultas Ekonomika dan Bisnis Universitas Dipenogoro.

Mustofa, Fauzi A., Kertahadi, dan Mirza Maulinarhadi R.. 2016. Pengaruh Pemahaman Peraturan Perpajakan, Tarif Pajak, dan Asas Keadilan terhadap Kepatuhan Wajib Pajak. Jurnal Perpajakan (JEJAK), 8(1), h:1-7.

Muliari, Ni Ketut dan Putu Ery Setiawan. 2011. Pengaruh Persepsi tentang Sanksi Perpajakan dan Kesadaran Wajib Pajak pada Kepatuhan Pelaporan Wajib Pajak Orang Pribadi di Kantor Pelayanan Pajak Pratama Denpasar Timur. Jurnal Akuntansi dan Bisnis, Vol 2.

Novitasari. Fin-fin. 2006. Analisis Faktor-faktor yang Mempengaruhi Kepatuhan Wajib Pajak dalam Memenuhi Kewajiban Pajak. Skripsi Universitas Kristen Petra. 
Palda, Filip dan Jan Hanousek. 2002. Quality of Government Services and the Civic Duty to Pay Taxes in the Czech and Slovak Republics, and other Transition Countries.

Palil, M. Rizal. 2005 Does Tax Knowledge Matter in Self Assessment System? Evidence from Malaysia Tax Administrative. The Journal of American Academy of Business, 2. Cambridge.

Paramartha, I Putu Indra Pradnya. 2016. Pengaruh Kualitas Pelayanan, Pengetahuan dan Sanksi Perpajakan terhadap Kepatuhan Wajib Pajak Badan. E-jurnal Akuntansi Universitas Udayana, 15 (1), h:641-666.

Parasuraman, Zeithaml, Berry. 1985. A Conceptual Model of Service Quality Its Implication Future Research. Journal of Marketing, 49, pp:41-50.

Poulson, Barry W., Kaplan, Jules Gordon. 2008. State Income Taxes and Economics Growth. Cato Journal, vol.28, no.1, page 53-71.

Pratiwi, Agustini Eka. 2015. Pengaruh Sistem Modernisasi dan Sanksi Perpajakan pada Kepatuhan Wajib Pajak di Kantor Pelayanan Pajak Pratama Denpasar Timur. Skripsi Jurusan Akuntansi Fakultas Ekonomi dan Bisnis Universitas Udayana.

Rahayu. 2010. Perpajakan Indonesia-Konsep dan Aspek Formal. Jakarta: Graha Ilmu.

Sanders, Debra L., Philip M. J. Reckers \& Govind S. Iyer. 2008. Influence of Accountability and Penalty Awareness on Tax Compliance. American Accounting Association. Vol 30(2) : Hal. 1-20.

Sandmo, A. 2005. The Theory of Tax Evasion: A Retrospective view. National Tax Journal, 53 (4), pp:643-648.

Santi, Anisa Nirmala. 2012. Analisis Pengaruh Kesadaran Perpajakan, Sikap Rasional, Lingkungan, Sanksi Denda, dan Sikap Fiskus terhadap Kepatuhan Wajib Pajak (Studi Empiris pada WPOP di Wilayah KPP Pratama Semarang). Skripsi Program Sarjana Fakultas Ekonomika dan Bisnis Universitas Diponegor.

Siregar, Yuli Anita dkk. 2012. Pengaruh Pelayanan Fiskus dan Pengetahuan Perpajakan terhadap Kepatuhan Wajib Pajak (Studi Empiris terhadap Wajib Pajak di Semarang Tengah). Jurnal Ilmu Administrasi Bisnis. Universitas Diponegoro Semarang.

Sugiyono. 2014. Metodologi Penelitian Bisnis. Bandung: Alfabeta. 
Suryanti, Tri. 2013. Pengaruh Tingkat Kepatuhan Wajib Pajak Badan terhadap Peningkatan Penerimaan Pajak Penghasilan dengan Penagihan Pajak sebagai Variabel Moderating. Skripsi Jurusan Akuntansi Fakultas Ekonomi dan Bisnis Universitas Islam Negeri Syarif Hidayatullah. Jakarta.

Susilawati, Ketut Evi dan Ketut Budiartha. 2013. Pengaruh Kesadaran Wajib Pajak, Pengetahuan Pajak, Sanksi Perpajakan dan Akuntabilitas Pelayanan Publik pada Kepatuhan Wajib Pajak Kendaraan Bermotor. E-Jurnal Akuntansi Univeristas Udayana, 4 (2), h:345-357.

Susmita, Rara. 2015. Pengaruh Kualitas Pelayanan, Sanksi Perpajakan, Biaya Kepatuhan Pajak, dan Penerapan E-Filing pada Kepatuhan Wajib Pajak. Skripsi Jurusan Akuntansi Fakultas Ekonomi dan Bisnis Universitas Udayana.

Susmita, Rara dan Ni Luh Supadmi. 2016. Pengaruh Kualitas Pelayanan, Sanksi Perpajakan, Biaya Kepatuhan Pajak, dan Penerapan E-Filing pada Kepatuhan Wajib Pajak. E-jurnal Akuntansi Universitas Udayana, 14 (2), h:1239-1269.

Syahril, Farid. 2013. Pengaruh Tingkat Pemahaman Wajib Pajak dan Kualitas Pelayanan Fiskus terhadap Tingkat Kepatuhan Wajib Pajak PPh Orang Pribadi (Studi Empiris pada KPP Pratama Kota Solok). Skripsi Program Studi Akuntansi Fakultas Ekonomi Universitas Negeri Padang.

Tiraada, Tryana A.M.. 2013. Kesadaran Perpajakan, Sanksi Pajak, Sikap Fiskus terhadap Kepatuhan WPOP di Kabupaten Minahasa Selatan. Jurnal EMBA, 1 (3), h:999-1008.

Trisnayanti, IA Ivon dan I Ketut Jati. 2015. Pengaruh Self Assessment System, Pemeriksaan Pajak, dan Penagihan Pajak pada Penerimaan Pajak Pertambahan Nilai (PPN). E-Jurnal Akuntansi Universitas Udayana, 13(1), h:292-310.

Umar, Husein. 2008. Metode Riset Bisnis. Jakarta: PT Gramedia Pustaka Utama.

Webley, P., H. Robben., H. Elffers dan D. Hessing. 1991. Tax Evasion: An Experimental Approach. Cambridge, United Kingdom: Cambridge University Press.

Widyastuti, Ella. 2015. Pengaruh Tingkat Pemahaman Wajib Pajak, Kualitas Pelayanan Fiskus, Sanksi Perpajakan, dan Lingkungan Wajib Pajak terhadap Tingkat Kepatuhan Wajib Pajak Orang Pribadi. Naskah Publikasi Program Studi Akuntansi Fakultas Ekonomi dan Bisnis Universitas Muhammadiyah Surakarta. 
Putri Noviantari dan Putu Ery Setiawan. Pengaruh ...

Winerungan, Oktaviane L. 2013. Sosialisasi Pepajakan, Pelayanan Fiskus dan Sanksi Perpajakan terhadap Kepatuhan WPOP di KPP Manado dan KPP Bitung. Jurnal EMBA, 1 (3), h:960-970. 